\title{
PENATAAN SUMBER DAYA MANUSIA APARATUR DAERAH BERBASIS KOMPETENSI
}

\section{ARRANGEMENT OF LOCAL APPARATUS BASED ON COMPETENCE}

\author{
Irma Purnamasari1', R. Akhmad Munjin², Ike A Ratnamulyani ${ }^{3}$ \\ 1,2Program Studi Administrasi Publik, Fakultas Ilmu Sosial dan Ilmu Politik, Universitas \\ Djuanda, Jl. Tol Ciawi No. 1, Kotak Pos 35 Bogor 16720 \\ ${ }^{3}$ Program Studi Sains Komunikasi, Fakultas Ilmu Sosial dan Ilmu Politik, Universitas \\ Djuanda, Jl. Tol Ciawi No. 1, Kotak Pos 35 Bogor 16720 \\ ${ }^{*}$ Korespondensi: Irma Purnamasari. Email: irma.purnamasari@unida.ac.id
}

(Diterima: 1 Februari 2019; Ditelaah: 25 Februari 2019; Disetujui: 22 Maret 2019)

\begin{abstract}
The implementation of Regional Government is directed at accelerating the realization of community welfare through improving services, empowerment, and community participation. In an effort to achieve the above goals, apparatus with the right, professional and competent numbers are needed. In line with the principles of professionalism and objectivity that are required in the law on staffing matters, the Bureaucratic Reformation in the Regional Government needs to conduct competency-based Apparatus Resource Arrangements. Presidential Regulation Number 81 of 2010 concerning Grand Design of Bureaucratic Reform explains that the main problem of state apparatus HR is the allocation in terms of quantity, quality, and distribution of civil servants according to unequal territorial (regional), and low levels of civil servant productivity. Structuring the human resources of the apparatus has not been optimally implemented to improve professionalism, employee performance, and organization. The research method used is descriptive qualitative through (1) desk study (study of literature and documents) and (2) field study (field study) that uses observation and interview techniques. Competency-based Apparatus Resource Management implies the need for the availability of information relating to competence. In this case the two main pillars are the competencies required by the office, commonly referred to as Position Competency Standards and the competencies possessed by employees.
\end{abstract}

Keywords: Apparatus HR Management, Employee Competence, Regional Apparatus HR.

\begin{abstract}
ABSTRAK
Penyelenggaraan Pemerintahan Daerah diarahkan untuk mempercepat terwujudnya kesejahteraan masyarakat melalui peningkatan pelayanan, pemberdayaan, dan peran serta masyarakat. Dalam upaya pencapaian tujuan di atas dibutuhkan Sumber Daya Aparatur dengan jumlah yang tepat, profesional dan memiliki kompetensi. Sejalan dengan prinsip-prinsip profesionalisme dan objektivitas yang diminta dalam Undang - Undang pokok-pokok kepegawaian, maka Reformasi Birokrasi di lingkungan Pemerintahan Daerah perlu melakukan Penataan Sumber Daya Aparatur yang berbasis kompetensi. Peraturan Presiden Nomor 81 Tahun 2010 tentang Grand Design Reformasi Birokrasi menerangkan bahwa masalah utama SDM aparatur negara adalah alokasi dalam hal kuantitas, kualitas, dan distribusi PNS menurut teritorial (daerah) tidak seimbang, serta tingkat produktivitas PNS masih rendah. Penataan sumber daya manusia aparatur belum dilaksanakan secara optimal untuk meningkatkan profesionalisme, kinerja pegawai, dan organisasi. Metode penelitian yang digunakan adalah deskriptif kualitatif melalui (1) desk study (studi literatur dan dokumen) dan (2) field study (studi lapangan) yang menggunakan teknik observasi dan wawancara. Manajemen Sumber Daya Aparatur berbasis kompetensi mengisyaratkan perlunya ketersediaan informasi yang berkaitan dengan kompetensi. Dalam hal ini dua pilar utamanya adalah kompetensi yang dipersyaratkan oleh jabatan, lazim disebut dengan Standar Kompetensi Jabatan dan kompetensi yang dimiliki oleh pegawai.
\end{abstract}

Kata Kunci: Penataan, Kompetensi Pegawai, Sumber Daya Manusia Aparatur Daerah. 


\section{PENDAHULUAN}

Dalam upaya memberikan pelayanan yang prima kepada masyarakat dan dalam rangka menjalankan penyelenggaraan tugas-tugas pemerintahan, Pemerintah Daerah sangat membutuhkan sumber daya aparatur yang memiliki kompetensi dan kinerja yang baik serta profesional di bidang penyelenggaraan pemerintahan yang mendukung proses penyelenggaraan tersebut. Menurut Lako dan Sumaryati (2002) SDM yang berkualitas memiliki empat ciri. Pertama, memiliki kompetensi yang memadai baik dari segi knowledge, skill, abilities, dan experience. Kedua, memiliki komitmen yang tinggi terhadap organisasi. Ketiga, dapat bertindak efektif dan efisien dalam melakukan tugasnya. Terakhir, dapat bertindak selaras antara tujuan pribadi dan tujuan organisasi. Semakin tinggi jabatan seseorang dalam suatu organisasi, diharapkan makin menampilkan keempat ciri SDM yang berkualitas tersebut. Kompetensi dan kinerja yang handal merupakan salah satu faktor kunci yang menentukan keberhasilan Pemerintah Daerah dalam mencapai tujuan organisasinya.

Dalam rangka menjamin tersedianya jumlah Pegawai Negeri Sipil yang tepat dalam memberikan pelayanan publik, diperlukan penataan SDM aparatur berbasis kompetensi di daerah. Penataan SDM aparatur meliputi aspek kuantitas, kualitas, komposisi, dan distribusi. Namun tahap pertama diatur penataan Aspek Kuantitas PNS yang ada sehingga diperoleh jumlah pegawai yang sesuai dengan kebutuhan organisasi seperti yang jelaskan dalam Peraturan Kepala BKN Nomor 37 Tahun 2011 tentang Pedoman Penataan PNS. Secara kuantitas, jumlah pegawai di lingkungan pemerintah Kota Bogor sudah memadai, namun masih terdapat beberapa jabatan yang belum memenuhi standar kompetensi yang dipersyaratkan.

Adapun tujuan penelitian ini adalah untuk menjamin tersedianya jumlah Pegawai Negeri Sipil yang tepat dalam memberikan pelayanan publik, serta untuk meningkatkan kinerja dan profesionalisme sumber daya aparatur negara, khususnya Pemerintah Daerah Kota Bogor melalui penataan SDM aparatur berbasis kompetensi.

\section{MATERI DAN METODE}

\section{Teori yang Relevan}

Seiring dengan perkembangan teknologi dan lingkungan yang cepat pada setiap aspek kehidupan manusia, pemerintah daerah membutuhkan SDM aparatur yang memiliki kompetensi agar dapat memberikan pelayanan yang memuaskan kepada masyarakat. Beberapa ahli berpandangan bahwa komepetensi seseorang akan mengahasilkan kinerja dengan rumus kompetensi $=$ kinerja. Menurut Jimmy L Gaol, kinerja merupakan sesatu yang lebih dari sekedar fungsi motivasi dan keterampilan. Kinerja juga dipengaruhi oleh lingkunagn organisasi, yang melibatkan proses dan sistem. Konsekuensinya adalah organisasi memerlukan SDM yang memiliki keahlian dan kemampuan unik sesuai dengan visi dan misi organisasi.

Penataan SDM aparatur berbasis kompetensi dilakukan agar kinerja pegawai sesuai dengan kebutuhan dan tujuan organisasi serta dapat mewujudkan visi dan misi organisasi. Penataan SDM aparatur adalah suatu proses yang sistematis dan berkelanjutan untuk memperoleh kuantitas, kualitas, komposisi dan distribusi pegawai tepat sesuai dengan kebutuhan organisasi, sehingga dapat mewujudkan visi dan misi organisasi menjadi kinerja nyata. Peraturan Kepala Badan Kepegawaian Negara Nomor 37 Tahun 2011 Tentang Pedoman Penataan Pegawai Negeri Sipil pasal 2 setiap pejabat pembina kepegawaian pusat dan daerah wajib melakukan penataan pegawai negeri sipil di lingkungannya untuk memperoleh Pegawai Negeri Sipil yang tepat baik secara kuantitas, kualitas, komposisi, dan distribusinya secara proporsional sehingga dapat mewujudkan visi dan misi organisasi menjadi kinerja nyata. 
Merujuk pada Peraturan Kepala Badan Kepegawaian Negara Nomor 37 Tahun 2011 Tentang Pedoman Penataan Pegawai Negeri Sipil, Penataan PNS dilaksanakan berdasarkan prinsip:

1. Terencana, yaitu penataan PNS dilaksanakan melalui suatu persiapan yang komprehensif berdasarkan suatu rancangan dan konsep dalam dimensi waktu yang telah ditentukan.

2. Sistematis, yaitu penataan PNS dilaksanakan menurut pendekatan suatu sistem tertentu yang mengacu pada Sistem Manajemen Kepegawaian.

3. Objektif, yaitu penataan PNS dilaksanakan sesuai dengan kebutuhan riil organisasi.

4. Berkelanjutan, yaitu penataan PNS merupakan proses yang berkesinambungan sesuai dengan tahapan perencanaan yang sistematis.

Kompetensi menurut Peraturan Kepala Badan Kepegawaian Negara Nomor 7 Tahun 2013 tentang Pedoman Penyusunan Standar Kompetensi Manajerial Pegawai Negeri Sipil adalah karakteristik dan kemampuan kerja yang mencakup aspek pengetahuan, keterampilan, dan sikap sesuai tugas dan/atau fungsi jabatan. Kompetensi Manajerial adalah soft competency yang mencakup aspek pengetahuan, keterampilan, dan sikap sesuai tugas dan/atau fungsi jabatan. Standar Kompetensi Manajerial PNS adalah persyaratan kompetensi manajerial minimal yang harus dimiliki seorang PNS dalam melaksanakan tugas jabatan.

Sedangkan Jimmy L Gaol mengartikan kompetensi sebagai kemampuan seseorang yang dapat terobservasi yang mencakup pengetahuan, keterampilan, dan sikap dalam menyelesaikan suatu pekerjaan atau tugas sesuai dengan performance yang ditetapkan. Menurut Watson Wyatt (dalam Ruky, 2003: 106), competency merupakan kombinasi dari ketrampilan (skill), pengetahuan (knowledge), dan perilaku (attitude) yang dapat diamati dan diterapkan secara kritis untuk suksesnya sebuah organisasi dan prestasi kerja serta kontribusi pribadi karyawan terhadap organisasinya. Dari definisi tersebut dapat dilihat bahwa Watson Wyatt menggunakan istilah knowledges, skills dan attitudes atau KSA untuk konsep kompetensi.

Sedarmayanti (2007) menyebutkan bahwa reformulasi sumberdaya manusia aparatur untuk membangun birokrasi pemerintah dalam rangka peningkatan kapasitas aparatur harus terus diupayakan dengan penerapan kompetensi dengan profesionalisme dan budaya kerja secara berdisiplin, sehingga mempunyai kemampuan teknis tinggi yang pada tingkat tertentu juga diserta manajerial yang hebat dalam segala budaya kerja keras dan prestasi tinggi.

Meningkatnya kompetensi aparatur pemerintah daerah yang kompeten menjadi salah satu tujuan dalam rencana strategis 2015-2019 badan kepegawaian dan pengembangan sumber daya aparatur kota bogor, dengan sasaran terpenuhinya kebutuhan PNS sesuai kompetensi berdasarkan kebutuhan organisasi, serta indikator sasaran: jumlah aparatur pemerintah daerah yang sesuai kompetensi.

Jenis kompetensi menurut Spencer dan Spencer dalam Marwansyah (2010: 3840) mengacu pada kompetensi yang dimiliki individu yang dapat dibedakan menjadi enam kluster kompetensi sebagai berikut:

1. Kompetensi berprestasi dan bertindak (achievement and action), esensi kluster ini adalah dorongan untuk bertindak dari seseorang dan pengaruhnya terhadap penigkatan prudktivitas.

2. Kompetensi pelayanan (helping and human service), Esensi kluster ini termasuk kesungguhan dalam memahami keinginan, kepentingan dan kebutuhan orang serta termasuk kebutuhan orang yang akan dilanyaninya.

3. Kompetensi mempengaruhi orang lain (impact and influence), esensi pada 
kluster ini adalah kemampuan dirinya dalam mempengaruhi orang lain

4. Kompetensi manajerial (managerial), esensi kluster ini mengacu kepada kemampuan khusus dalam pengelolaan sumber daya organisasi.

5. Kompetensi keahlian (cognitive), yang menjadi esensi dari kompetensi ini adalah kemampuan individu dalam memahami situasi, tugas, masalah dan peluang yang ada melalui pengetahuan tertentu.

6. Efektivitas diri (personal effectiveness), yang menjadi esensi dari kompetensi ini merefleksi pada kedewasaan seseorang dalam hubungannya denga orang lain dalam pekerjaan.

\section{Metode Penelitian}

Metode penelitian yang digunakan adalah penelitian deskriptif-kualitatif. Pemilihan pendekatan kualitatif dengan metode deskriptif, didasarkan pada tujuan untuk memperoleh deskripsi yang utuh dan realistis tentang penataan SDM aparatur Pemerintah Daerah. Adapun Teknik pengumpulan data yang dilakukan adalah melalui wawancara, dokumentasi, dan observasi. Wawancara dilakukan terhadap 4 orang informan dari berbagai jenis unit kerja, yaitu Kepala dan Pegawai Badan Kepegawaian dan Pengembangan Sumber Daya Aparatur Kota Bogor, perwakilan kepala Dinas, perwakilan Camat, dan perwakilan Lurah. Analisis data dilakukan melalui analisis deskriptif kualitatif.

Dalam mengumpulkan data, cara-cara yang dilakukan peneliti dalam mengumpulkan data adalah (a) Studi Kepustakaan (buku, dokumen, dan berbagai macam literatur yang berhubungan dengan kebijakan SDM aparatur), (b) Studi Lapangan dengan cara (1) Observasi, (2) Wawancara (terhadap 4 orang informan dari berbagai jenis unit kerja, yaitu perwakilan Badan Kepegawaian dan Pengembangan Sumber Daya Aparatur Kota Bogor, perwakilan Dinas, perwakilan Camat, dan perwakilan
Lurah). Adapun teknik analisa data yang digunakan dalam penelitian ini adalah (1) Data primer (data yang diperoleh secara langsung dari informan), (2) Data sekunder ( data yang diperoleh dari dokumen dan arsip-arsip), dengan menguraikan, menafsirkan, dan menggambarkan data yang terkumpul secara sistemik dan sistematik. Untuk menyajikan data tersebut agar lebih bermakna dan mudah dipahami digunakan interactive model analysis dari Milles dan Huberman (1992). Kegiatan analisis dalam model ini dibagi menjadi tiga tahap, yaitu reduksi data, penyajian data, dan penarikan simpulan.

\section{HASIL DAN PEMBAHASAN}

Secara geografis Kota Bogor terletak diantara $106^{\circ} 48^{\prime} \mathrm{BT}$ dan $6^{\circ} 26^{\prime} \mathrm{LS}$, dengan Luas wilayah sebesar $11.850 \mathrm{Ha}$, kedudukan geografis kota Bogor di tengahtengah wilayah Kabupaten Bogor serta lokasi nya sangat dekat dengan wilayah Ibu Kota Negara, merupakan potensi yang strategis bagi perkembangan dan pertumbuhan ekonomi dan jasa, pusat kegiatan nasional untuk industri, perdagangan, transportasi, komunikasi dan pariwisata. Penduduk Kota Bogor terdapat sebanyak 1.064.687 orang yang terdiri atas 540.288 laki-laki dan sebanyak 524.399 orang perempuan dibandingkan tahun sebelumnya, jumlah penduduk kota Bogor bertambah sebanyak 16.765 orang atau meningkat sebanyak 1,60\%. Dengan luas wilayah $11.850 \mathrm{KM}$ persegi kepadatan penduduk di Kota Bogor pada tahun 2016 mencapai 8.985 orang per KM persegi.

Pelayanan yang ekstra bagi pemenuhan kebutuhan warga juga menjadi tuntutan utama karena semakin berkembang dan beragamnya kebutuhan seluruh warga terhadap barang dan jasa. Implikasi dari semua ini adalah meningkatnya kebutuhan pengadaan sarana transportasi masyarakat kota, timbulnya kemacetan, meningkatnya jumlah pedagang kaki lima, kurang teraturnya penataan kota, menurunnya kualitas kebersihan kota sebagai akibat 
dari padatnya penduduk dan segala aktivitasnya yang melebihi daya dukung lingkungan.

Dalam menjalankan pemerintahannya, Kota Bogor terbagi menjadi 6 kecamatan dan 68 kelurahan serta 31 perangkat daerah. Sampai dengan Tahun 2016 jumlah pegawai negeri di lingkungan pemerintah Kota Bogor tercatat sebanyak 7.732 orang yang terdiri atas 3.870 laki-laki dan sisanya sebanyak 3.862 perempuan. Pegawai negeri di Kota Bogor menurut golongan gaji terdiri atas golongan I sebanyak 288 orang, golongan II sebanyak 1.775 orang, golongan III sebanyak 3.396 orang dan golongan IV sebanyak 2.273 orang. Sedangkan menurut pendidikan yang ditamatkan, terdapat sebanyak 232 orang berpendidikan sekolah dasar, sebanyak 210 orang berpendidikan SLTP, sebanyak 1.931orang berpendidikan SLTA. Selanjutnya terdapat sebanyak 817 orang berpendidikan diploma, dan sebanyak 3.934 orang berpendidikan strata 1 dan sebanyak 605 orang berpendidikan strata II/III. Jumlah pegawai yang menduduki jabatan struktural di lingkungan Pemerintah Kota Bogor sebanyak 945 orang. Secara rinci jumlah PNS yang menduduki jabatan struktural berdasarkan perangkat daerah di lingkungan Pemerintah Kota Bogor disajikan dalam Tabel 1.

Tabel. 1

Rekapitulasi PNS Kota Bogor yang Menduduki Jabatan Struktural

\begin{tabular}{|c|l|c|}
\hline No. & Unit Kerja Kan & Jumlah \\
\hline 1 & $\begin{array}{l}\text { Badan Kepegawaian dan } \\
\text { Pengembangan Sumber Daya } \\
\text { Aparatur Kota Bogor }\end{array}$ & 5 \\
\hline 2 & $\begin{array}{l}\text { Badan Penanggulangan Bencana } \\
\text { Daerah Kota Bogor }\end{array}$ & 15 \\
\hline 3 & $\begin{array}{l}\text { Badan Pendapatan Daerah Kota } \\
\text { Bogor }\end{array}$ & 16 \\
\hline 4 & $\begin{array}{l}\text { Badan Pengelolaan Keuangan dan } \\
\text { Aset Daerah Kota Bogor }\end{array}$ & $\begin{array}{l}\text { Badan Perencanaan Pembangunan } \\
\text { Daerah Kota Bogor }\end{array}$ \\
\hline 6 & $\begin{array}{l}\text { Dinas Kearsipan dan Perpustakaan } \\
\text { Kota Bogor }\end{array}$ & 14 \\
\hline 7 & $\begin{array}{l}\text { Dinas Kependudukan dan } \\
\text { Pencatatan Sipil Kota Bogor }\end{array}$ \\
\hline
\end{tabular}

\begin{tabular}{|c|c|c|}
\hline 8 & Dinas Kesehatan Kota Bogor & 46 \\
\hline 9 & $\begin{array}{l}\text { Dinas Ketahanan Pangan Kota } \\
\text { Bogor }\end{array}$ & 16 \\
\hline 10 & $\begin{array}{l}\text { Dinas Komunikasi, Informatika, } \\
\text { Statistik dan Persandian Kota Bogor }\end{array}$ & 21 \\
\hline 11 & $\begin{array}{l}\text { Dinas Koperasi, Usaha Kecil dan } \\
\text { Menengah Kota Bogor }\end{array}$ & 15 \\
\hline 12 & $\begin{array}{l}\text { Dinas Lingkungan Hidup Kota } \\
\text { Bogor }\end{array}$ & 23 \\
\hline 13 & $\begin{array}{l}\text { Dinas Pariwisata dan Kebudayaan } \\
\text { Kota Bogor }\end{array}$ & 20 \\
\hline 14 & $\begin{array}{lcc}\text { Dinas Pekerjaan } & \text { Umum } & \text { dan } \\
\text { Penataan Ruang Kota Bogor } & \\
\end{array}$ & 24 \\
\hline 15 & $\begin{array}{l}\text { Dinas Pemberdayaan Masyarakat, } \\
\text { Perempuan, dan Perlindungan Anak } \\
\text { Kota Bogor }\end{array}$ & 16 \\
\hline 16 & $\begin{array}{l}\text { Dinas Pemuda dan Olahraga Kota } \\
\text { Bogor }\end{array}$ & 19 \\
\hline 17 & $\begin{array}{l}\text { Dinas Penanaman Modal dan } \\
\text { Pelayanan Terpadu Satu Pintu Kota } \\
\text { Bogor }\end{array}$ & 21 \\
\hline 18 & Dinas Pendidikan Kota Bogor & 20 \\
\hline 19 & $\begin{array}{l}\text { Dinas Pengendalian Penduduk dan } \\
\text { Keluarga Berencana Kota Bogor }\end{array}$ & 11 \\
\hline 20 & Dinas Perhubungan Kota Bogor & 18 \\
\hline 21 & $\begin{array}{lcc}\text { Dinas } & \text { Perindustrian } & \text { dan } \\
\text { Perdagangan Kota Bogor } & \end{array}$ & 19 \\
\hline 22 & Dinas Pertanian Kota Bogor & 21 \\
\hline 23 & $\begin{array}{l}\text { Dinas Perumahan dan Permukiman } \\
\text { Kota Bogor }\end{array}$ & 16 \\
\hline 24 & Dinas Sosial Kota Bogor & 17 \\
\hline 25 & $\begin{array}{lccc}\text { Dinas } & \text { Tenaga } & \text { Kerja } & \text { dan } \\
\text { Transmigrasi Kota Bogor } & \\
\end{array}$ & 14 \\
\hline 26 & Inspektorat Kota Bogor & 6 \\
\hline 27 & $\begin{array}{l}\text { Kantor Kesatuan Bangsa Dan Politik } \\
\text { Kota Bogor }\end{array}$ & 4 \\
\hline 28 & Kecamatan Bogor Barat Kota Bogor & 86 \\
\hline 29 & $\begin{array}{l}\text { Kecamatan Bogor Selatan Kota } \\
\text { Bogor }\end{array}$ & 85 \\
\hline 30 & $\begin{array}{l}\text { Kecamatan Bogor Tengah Kota } \\
\text { Bogor }\end{array}$ & 62 \\
\hline 31 & Kecamatan Bogor Timur Kota Bogor & 38 \\
\hline 32 & Kecamatan Bogor Utara Kota Bogor & 47 \\
\hline 33 & $\begin{array}{l}\text { Kecamatan Tanah Sareal Kota } \\
\text { Bogor }\end{array}$ & 62 \\
\hline 34 & RSUD Kota Bogor & 18 \\
\hline 35 & $\begin{array}{l}\text { Satuan Polisi Pamong Praja Kota } \\
\text { Bogor }\end{array}$ & 21 \\
\hline 36 & Sekretariat Daerah Kota Bogor & 40 \\
\hline 37 & Sekretariat DPRD Kota Bogor & 13 \\
\hline \multirow[t]{2}{*}{38} & Sekretariat KPU Kota Bogor & 5 \\
\hline & Jumlah & 945 \\
\hline
\end{tabular}

Sumber: Badan Kepegawaian dan Pengembangan Sumber Daya Aparatur Kota Bogor 2018.

Berdasarkan hasil identifikasi awal jabatan, terdapat 945 pejabat struktural yang berasal dari seluruh perangkat daerah di lingkungan Pemerintah Kota Bogor. 
Jumlah pejabat struktural di setiap perangkat daerah beragam, mulai dari yang terendah 4 pejabat struktural sampai yang tertinggi 86 pejabat struktural.

\section{Penataan SDM Aparatur}

Dalam rangka menjamin tersedianya jumlah PNS yang tepat dalam memberikan pelayanan publik, diperlukan penataan SDM aparatur berbasis kompetensi di daerah. Penataan penataan SDM aparatur meliputi aspek kuantitas, kualitas, komposisi, dan distribusi. Namun tahap pertama diatur penataan Aspek Kuantitas PNS yang ada sehingga diperoleh jumlah pegawai yang sesuai dengan kebutuhan organisasi seperti yang jelaskan dalam Peraturan Kepala BKN Nomor 37 Tahun 2011 tentang Pedoman Penataan PNS.

Berdasarkan Peraturan Kepala Badan Kepegawaian Negara Nomor 37 Tahun 2011 tentang Pedoman Penataan Pegawai Negeri Sipil, penataan PNS adalah suatu proses yang sistematis dan berkelanjutan untuk memperoleh kuantitas, kualitas, komposisi dan distribusi pegawai yang tepat sesuai dengan kebutuhan organisasi, sehingga dapat mewujudkan visi dan misi organisasi menjadi kinerja nyata. Berdasarkan peraturan tersebut, maka prosedur penataan SDM aparatur/pegawai menempuh tahapan sebagai berikut:

Pertama: Prinsip Penataan. Penataan SDM aparatur/pegawai memenuhi empat prinsip, yaitu: (1) Terencana, yaitu penataan pegawai dilaksanakan melalui suatu persiapan yang komprehensif berdasarkan suatu rancangan dan konsep dalam dimensi waktu yang telah ditentukan. (2) Sistematis, yaitu penataan pegawai dilaksanakan menurut pendekatan suatu sistem tertentu yang mengacu pada Sistem Manajemen Kepegawaian. (3) Objektif, yaitu penataan pegawai dilaksanakan sesuai dengan kebutuhan riil organisasi. (4) Berkelanjutan, yaitu penataan pegawai merupakan proses yang berkesinambungan sesuai dengan tahapan perencanaan yang sistematis.
Kedua: Persiapan Penataan. Persiapan penataan SDM aparatur/pegawai menempuh langkah, yaitu: (1) Dalam pelaksanaan penataan pegawai, Instansi Pusat dan Daerah wajib melakukan analisis jabatan dengan berpedoman pada peraturan perundang-undangan yang menghasilkan informasi jabatan meliputi: (a) Uraian jabatan. (b) Syarat jabatan; (c) Peta jabatan dan kekuatan pegawai. (2) Apabila informasi jabatan telah tersedia, maka instansi pusat dan daerah wajib melakukan peninjauan kembali atas informasi jabatan tersebut. (3) Untuk mempermudah dalam menyusun atau meninjau kembali informasi jabatan, instansi dapat menggunakan contoh informasi jabatan yang telah disusun oleh instansi lain sesuai dengan peraturan perundang-undangan.

Ketiga: Pelaksanaan Penataan. Pelaksanaan penataan SDM aparatur/ pegawai menempuh langkah, yaitu: (1) Menghitung kebutuhan pegawai dilakukan sesuai dengan peraturan perundang-undangan. (2) Menganalisis kesenjangan antara profil PNS dengan syarat jabatan. (3) Menentukan kategori jumlah pegawai pada Instansi Pusat dan Daerah dengan cara membandingkan antara hasil penghitungan kebutuhan pegawai setiap jabatan dengan jumlah pegawai yang ada. Kategori jumlah pegawai berupa kurang (K), sesuai $(\mathrm{S})$, dan lebih (L). (4) Melakukan langkah-langkah tindak lanjut sebagai berikut:

Langkah pertama adalah instansi yang termasuk dalam kategori jumlah pegawai kurang (K): (a) Melakukan distribusi pegawai dari unit organisasi yang kelebihan kepada unit organisasi yang kekurangan. (b) Penarikan PNS yang dipekerjakan atau diperbantukan pada instansi lain disesuaikan dengan syarat jabatan. (c) Memberdayakan dengan cara memberikan pendidikan dan pelatihan serta memperkaya tugas pegawai yang ada untuk melaksanakan tugas dan fungsi yang tidak dapat dilaksanakan karena kekurangan pegawai. (d) Menyusun perencanaan pengembangan pegawai. (e) Menyusun perencanaan pegawai untuk 5 (lima) tahun 
ke depan dengan pendekatan positive growth atau melaksanakan penerimaan pegawai dengan jumlah lebih besar dibandingkan pegawai yang berhenti, dilakukan secara bertahap sesuai dengan kemampuan keuangan negara.

Langkah kedua adalah instansi yang termasuk dalam kategori jumlah pegawai sesuai (S): (a) Melakukan distribusi pegawai dari unit organisasi yang kelebihan kepada unit organisasi yang kekurangan. (b) Melakukan pemetaan potensi dalam rangka mengetahui minat dan bakat pegawai. (c) Mengangkat PNS yang menduduki jabatan fungsional umum ke dalam jabatan fungsional tertentu sesuai dengan kebutuhan instansi dan mengidentifikasi kebutuhan pendidikan dan pelatihannya. (d) Menyusun perencanaan pengembangan pegawai. (e) Menyusun perencanaan pegawai untuk 5 (lima) tahun ke depan dengan pendekatan zero growth atau melaksanakan penerimaan pegawai dengan jumlah sama dengan pegawai yang berhenti, dilakukan secara bertahap sesuai dengan kemampuan keuangan negara.

Langkah ketiga adalah instansi yang termasuk dalam kategori jumlah pegawai lebih (L): (a) Melakukan distribusi pegawai dari unit organisasi yang kelebihan kepada unit organisasi yang kekurangan. (b) Melakukan penilaian kinerja, penegakan disiplin PNS, dan penilaian kompetensi untuk mengetahui PNS yang memiliki kompetensi dan kapabilitas sesuai dengan syarat jabatan berdasarkan peraturan perundang-undangan yang berlaku. (c) Apabila hasil penilaian tersebut di atas menunjukan bahwa PNS yang memiliki kompetensi dan kapabilitas sesuai dengan syarat jabatan kurang dari jumlah yang dibutuhkan, maka dilakukan penyusunan peringkat bagi PNS yang belum memiliki kompetensi dan kapabilitas sesuai dengan syarat jabatan.

Merujuk pada Peraturan Kepala Badan Kepegawaian Negara Nomor 37 Tahun 2011 tentang Pedoman Penataan Pegawai Negeri Sipil, prinsip pertama penataan PNS adalah terencana, yaitu penataan PNS dilaksanakan melalui suatu persiapan yang komprehensif berdasarkan suatu rancangan dan konsep dalam dimensi waktu yang telah ditentukan, yaitu dimulai dengan menghitung kebutuhan pegawai, yang dilakukan sesuai dengan peraturan perundang-undangan. Dalam menghitung kebutuhan pegawai, Pemerintah Daerah Kota Bogor merujuk pada Peraturan Menteri Negara Pendayagunaan Aparatur Negara Dan Reformasi Birokrasi Nomor 26 Tahun 2011 tentang Pedoman Perhitungan Jumlah Kebutuhan Pegawai Negeri Sipil untuk Daerah.

Tahap selanjutnya menentukan kategori jumlah pegawai dengan cara membandingkan antara hasil penghitungan kebutuhan pegawai setiap jabatan dengan jumlah pegawai yang ada. Jumlah pegawai di lingkungan Pemerintah Kota Bogor masuk dalam kategori kurang, hal ini disebabkan moratorium selama beberapa tahun, sehingga terjadi kelangkaan profesi di bidang akuntansi dan teknis. Sumber daya aparatur yang terbatas ini menyebabkan kesulitan untuk mencari orang dalam jabatan.

Prinsip penataan PNS yang kedua adalah sistematis, yaitu penataan PNS dilaksanakan menurut pendekatan suatu sistem tertentu yang mengacu pada sistem manajemen kepegawaian. Yaitu dimulai dengan identifikasi awal jabatan. Maksud dari identifikasi awal jabatan adalah memberikan informasi awal mengenai jumlah dan jenis jabatan yang ada dalam suatu organisasi. Lokus identifikasi awal jabatan dalam penelitian ini adalah 4 perangkat daerah yang ada di lingkungan pemerintahan Kota Bogor yaitu satu perangkat daerah dalam bentuk badan, dinas, kantor dan kecamatan. Identifikasi awal jabatan yang dimaksud adalah gambaran jumlah dan jenis jabatan yang ada dalam lingkup organisasi Pemerintahan Kota Bogor.

Langkah berikutnya adalah menganalisis kesenjangan antara profil PNS dengan syarat jabatan. Terkait dengan 
syarat jabatan Sugiharto Pujangkoro menyatakan bahwa syarat jabatan adalah persyaratan minimal yang harus dipenuhi oleh orang yang menduduki suatu jabatan, agar ia dapat melaksanakan tugas-tugas yang dibebankan kepadanya dengan baik. Dalam tahapan ini, masih terdapat beberapa jabatan yang syarat jabatannya belum terpenuhi, sehingga masih terdapat kesenjangan jabatan dan penempatan yang tidak sesuai dengan kompetensinya.

Prinsip penataan PNS yang ketiga adalah sustainable atau berkelanjutan, yaitu penataan PNS merupakan proses yang berkesinambungan sesuai dengan tahapan perencanaan yang sistematis. Yaitu dengan melakukan analisis jabatan dengan berpedoman pada peraturan perundangundangan yang menghasilkan informasi jabatan meliputi: (a) Uraian jabatan; (b) Syarat jabatan; dan (c) Peta jabatan dan kekuatan pegawai.

Prinsip yang keempat adalah objektif yaitu penataan PNS dilaksanakan sesuai dengan kebutuhan riil organisasi. Yaitu berdasarkan hasil penghitungan kebutuhan pegawai di daerah dan hasil analisis jabatan. Penataan PNS di lingkungan pemerintahan Kota Bogor dilaksanakan sesuai dengan kebutuhan riil organisasi berdasarkan hasil penghitungan kebutuhan pegawai di daerah dan hasil analisis jabatan sudah dilakukan namun belum maksimal. Berdasarkan uraian poin sebelumnya, dalam beberapa tahapan penataan masih terkendala, seperti dalam analisis jabatan kendala yang ditemui adalah syarat jabatan belum terpenuhi sehingga masih terdapat kesenjangan jabatan dan penempatan yang tidak sesuai dengan kompetensinya, serta kompetensi yang dilihat dari latar belakang pendidikan tidak menjamin seorang pegawai memiliki kinerja yang optimal.

\section{KESIMPULAN}

Penataan PNS di lingkungan pemerintahan Kota Bogor dilaksanakan sesuai dengan kebutuhan riil organisasi berdasarkan hasil penghitungan kebutuhan pegawai di daerah dan hasil analisis jabatan sudah dilaksanakan namun belum maksimal. Dalam beberapa tahapan penataan masih terkendala, seperti dalam analisis jabatan kendala yang ditemui adalah syarat jabatan belum terpenuhi sehingga masih terdapat kesenjangan jabatan dan penempatan yang belum sesuai dengan kompetensinya, serta kompetensi yang dilihat dari latar belakang pendidikan tidak menjamin seorang pegawai memiliki kinerja yang optimal.

\section{UCAPAN TERIMA KASIH}

Terlaksananya penelitian ini tentunya terdapat kontribusi sejumlah pihak. Untuk itu, peneliti selayaknya menyampaikan terima kasih kepada: (a) Direktorat Riset dan Pengabdian Masyarakat, Direktorat Jenderal Penguatan Riset dan Pengembangan, Kementerian Riset, Teknologi dan Pendidi-kan Tinggi, yang telah membiayai penelitian ini sesuai dengan Kontrak Penelitian Nomor: 0826/K4/KM/2018 Tahun Anggaran 2018, (b) Direktorat Riset dan Pengabdian Masyarakat Universitas Djuanda Bogor, dan (c) Fakultas Ilmu Sosial dan Ilmu Politik Universitas Djuanda Bogor, yang telah memfasilitasi penelitian ini.

\section{DAFTAR PUSTAKA}

C. H. R. Jimmy L. Gaol. 2014. Human Capital Manajemen Sumber Daya Manusia, Konsep, Teori dan Pengembangan dalam Konteks Oganisasi Publik dan Bisnis. Jakarta: PT Grasindo.

Marwansyah. 2010. Manajemen Sumber Daya Manusia. Edisi Kedua. Cetakan Kesatu. Bandung: Penerbit Alfabeta.

Lako, Andreas dan Sumaryati, Anna. 2002. "Optimalisasi Kinerja Korporasi melalui Audit Kinerja Manajemen Sumber Daya Manusia". Usahawan, Nomor 10 Tahun XXXI, Oktober.

Sugiharto, Pujangkoro. 2004, Analisis Jabatan (Job Analysis). Medan: Universitas Sumatra Utara. 
Sedarmayanti. 2007. "Reformulasi Pengembangan Sumber Daya Manusia di Daerah". Jurnal Wacana Kinerja, Volume 10 Tahun 2007, Bandung: PKP2A I.

Peraturan Kepala Badan Kepegawaian Negara Nomor 37 Tahun 2011 tentang Pedoman Penataan Pegawai Negeri Sipil. 